\title{
Induction of IL-2 and IFN- $\gamma$ in BALB/c mice immunised with subunit influenza $A$ vaccine in combination with whole cell or acellular DTP vaccine
}

\author{
H. TAMIZIFAR, R. JENNINGS, S. A. ALI* and C. W. POTTER* \\ Department of Medical Microbiology and *Institute for Cancer Studies, University of Sheffield Medical School, \\ Beech Hill Road, Sheffield S10 2RX
}

\begin{abstract}
Splenocytes from mice immunised with two doses of subunit influenza $\mathrm{A} / \mathrm{Beijing} / 353 / 89$ vaccine mixed with whole cell DTP (wDTP), acellular DTP (aDTP) or PBS were collected 7 and 10 days after the second immunisation, and re-stimulated with subunit influenza vaccine or live virus in vitro. Interleukin-2 (IL-2) and interferon- $\gamma$ (IFN- $\gamma$ ) were assayed in supernates from these cultures by an ELISA procedure. Splenocytes from mice given subunit influenza vaccine in WDTP produced greater than two-fold and greater than five-fold responses of IL-2 and IFN- $\gamma$, respectively, compared with splenocytes from mice immunised with subunit vaccine alone. In contrast, the response of splenocytes from mice immunised with subunit vaccine in saline or aDTP was similar, significantly less than for vaccine in WDTP $(p<0.01)$ and only slightly greater than for controls $(p<0.05)$. The production of IL-2 and IFN- $\gamma$ by these spleen cells was not significantly different on days 7 and 10 post-immunisation. Previous reports have shown that wDTP and aDTP enhance the serum antibody response of mice to influenza vaccine, but wDTP enhanced the response 100-fold greater than aDTP, and induced greater IgG2a and IgG2b subclass antibody responses; this last result indicates a cell-mediated immune response to vaccine. The present studies confirm these earlier findings; furthermore, as the IL-2 and IFN- $\gamma$ responses of splenocytes are associated with Th-1 subset T-lymphocyte response, the findings indicate a cytotoxic T-cell response to immunisation. The results indicate that influenza vaccine combined with wDTP induced a cell-mediated response in mice, which could confer a more solid immunity to challenge virus infection.
\end{abstract}

\section{Introduction}

Influenza is a major cause of morbidity and mortality, particularly among the elderly and other at risk groups. The current available vaccines confer protection on only $60-90 \%$ of vaccinees, with a lower rate in the elderly population $[1,2]$, but reduce hospitalisation in a higher percentage of persons. The failure of these inactivated vaccines to protect a greater percentage of vaccinees may be due to several factors, including virus variation, vaccine preparation in eggs, poor local antibody production and lack of cell-mediated responses [3]; the importance of these responses in immunity has been reported in numerous studies $[4,5]$. In particular, studies in mice and human subjects

Received 28 Feb. 1996; revised version accepted 2 July 1996.

Corresponding author: Mr H. Tamizifar. suggest that MHC class-I restricted cytotoxic $T$ lymphocytes (CTL) may have a role in immunity to influenza $[5,6]$.

Inactivated influenza vaccines have been shown to produce serum antibody responses but poor CTL responses [7]. However, a measurable MHC class-1 $\mathrm{CD}^{+}$CTL response has been observed by others $[8,9]$. In contrast, a marked CTL response has been observed after live virus vaccine infection and this may be related to the more solid immunity seen following infection [3]. In earlier studies, subunit influenza A virus vaccine in diphtheria-tetanus-pertussis (DTP) vaccine was shown to give an enhanced serum $\operatorname{IgG}$ antibody response in mice, a broader $\mathrm{IgG}$ subclass antibody response and a more solid immunity against virus infection than that seen following immunisation with saline vaccines $[10,11]$. In addition, influenza vaccines in DTP induced serum $\operatorname{IgG2a}$ 
and $\operatorname{IgG} 2 \mathrm{~b}$ antibody responses which indicated a response of Th-1 subset lymphocytes [11,12], which are mediators of CTL responses. To test this more rigorously, the CTL response of mice to subunit influenza vaccine in saline, whole-cell DTP (wDTP) or acellular DTP (aDTP) was investigated. Lymphocyte cultures were prepared from groups of immunised mice and stimulated with either subunit influenza vaccine or live virus. The supernates were then removed and assayed for IL-2 and IFN- $\gamma$, which are secreted by Th-1 lymphocytes, to seek an explanation for the more solid immunity seen in mice immunised with vaccine in DTP, to provide further evidence of a CTL responses and to compare the relative merits of wDTP and aDTP in potentiating immune responses to influenza vaccine.

\section{Materials and methods}

\section{Influenza virus and virus vaccine}

Seed influenza virus A/Beijing/353/89 $\left(\mathrm{H}_{3} \mathrm{~N}_{2}\right)$ was kindly supplied by Dr T. Carstairs, Evans Medical, Speke, Liverpool. A virus pool was prepared by inoculating $0.2 \mathrm{ml}$ of a $10^{3}$ dilution of seed virus into the allantoic cavity of 10-11-day embryonated chicken eggs; after incubation at $37^{\circ} \mathrm{C}$ for $72 \mathrm{~h}$, allantoic fluids were harvested, sealed in ampoules and stored at $-70^{\circ} \mathrm{C}$. Virus infectivity was determined by inoculating $0.1 \mathrm{ml}$ of 10-fold dilutions of virus in phosphatebuffered saline (PBS), $\mathrm{pH} 7.2$, into embryonated eggs; inoculated eggs were incubated for $72 \mathrm{~h}$ at $33^{\circ} \mathrm{C}$ before the allantoic fluids were tested for virus by haemagglutination with fowl erythrocytes. From the results obtained the $50 \%$ egg infectivity dose (EID50) was calculated.

The influenza virus used for vaccine preparation was influenza virus $\mathrm{A} /$ Beijing $\mathrm{X} 109$, a reassortant of influenza viruses $A / B e i j i n g / 353 / 89\left(\mathrm{H}_{3} \mathrm{~N}_{2}\right)$ and $\mathrm{A} / \mathrm{PR} /$ $8 / 34\left(\mathrm{H}_{1} \mathrm{~N}_{1}\right)$. The subunit vaccine prepared from this virus was the influenza $A\left(\mathrm{H}_{3} \mathrm{~N}_{2}\right)$ component incorporated into the commercial purified influenza surface antigen vaccine 'Flurigen' for 1992/93, and was kindly supplied by Evans Medical. The concentration of haemagglutinin (HA) in the subunit vaccine was calculated by single radial diffusion. Standard reagents were kindly supplied by Dr J. Wood, National Institute for Biological Standards and Control, Potters Bar, London.

\section{Adjuvants}

Diphtheria, tetanus and whole cell pertussis vaccine (wDTP) and acellular DTP (aDTP) were kindly supplied by Evans Medical. In both cases these were inoculated into mice at a 1 in 4 dilution of the recommended human dose which was the highest dose tolerated by mice. Each mouse was inoculated with $5.0 \mu \mathrm{g}$ of virus HA in WDTP, aDTP or saline into the thigh; the inoculum of $0.225 \mathrm{ml}$ produced a bleb which disappeared within $1 \mathrm{~h}$ of inoculation.

\section{Animals}

$\mathrm{BALB} / \mathrm{c}$ mice were obtained from the closed, randomly bred colony held at the University of Sheffield. Mice were used at age $8-10$ weeks when their weight was $c$. $20-25 \mathrm{~g}$.

\section{Experimental protocol}

Three groups of $\mathrm{BALB} / \mathrm{c}$ mice (four animals/group) were immunised with $5 \mu \mathrm{g}$ of HA of subunit $\mathrm{A} / \mathrm{Beijing}$ X109 mixed with wDTP, aDTP or saline; further control groups received wDTP, aDTP or PBS alone. Two doses of each vaccine were given at 11-day intervals. Seven and 10 days after the second immunisation, the spleens of two mice in each group were removed, pooled and disrupted and the cells were further disassociated by gently flushing through a syringe and needle with $10 \mathrm{ml}$ of RPMI medium. To lyse the red blood cells, $5 \mathrm{ml}$ of RBC lysis solution $\left(\mathrm{NH}_{4} \mathrm{Cl} \quad 8.3 \mathrm{mg} / \mathrm{ml}, \mathrm{KHCO}_{3} \quad 1 \mathrm{mg} / \mathrm{ml}\right.$ and EDTA $37 \mu \mathrm{g} / \mathrm{ml}$ in distilled water) was added to the splenocyte cell pellet, the cells were lightly centrifuged and the supernate was discarded. For separation of $\mathrm{T}$ cells, the cell pellet in $2 \mathrm{ml}$ of RPMI media was layered into $5 \mathrm{ml}$ of separation media (Lymphoprep; Tech Gen International Ltd) in plastic universal tubes, and centrifuged at $1800 \mathrm{rpm}$; after this procedure, the interface layer containing the $T$ cells was collected, washed and counted in a trypan blue $1 \%$ solution to determine the number of viable cells.

For proliferation of $\mathrm{T}$ lymphocytes, feeder cells from normal mouse spleens were treated with mitomycin $\mathrm{C}$ $50 \mu \mathrm{g} / \mathrm{ml}$ and incubated for $30 \mathrm{~min}$ at $37^{\circ} \mathrm{C}$; the cells were then washed three times in RPMI containing fetal calf serum (FCS) $1 \%$, and counted as described above. Feeder cells $\left(2.5 \times 10^{6} / \mathrm{ml}\right.$ and $\mathrm{T}$ cells $\left(5 \times 10^{6} / \mathrm{ml}\right)$ were mixed together and dispensed in a volume of $200 \mu \mathrm{l} /$ well in a 96 -well tissue culture plate and stimulated with $2 \mu \mathrm{g}$ HA subunit influenza $\mathrm{A} /$ Beijing/353/89 virus/well or $2 \mu \mathrm{g}$ of live influenza $\mathrm{A} /$ Beijing/353/89 virus protein/well. The plates were incubated for 5-6 days at $37^{\circ} \mathrm{C}$ in an atmosphere of $\mathrm{CO}_{2} 5 \%$. After this time $100 \mu \mathrm{l}$ of supernate was collected aseptically and stored at $-70^{\circ} \mathrm{C}$ before determination of supernatant IL-2 and IFN- $\gamma$. Each measurement was carried out in eight wells and the mean value (and SD) was determined.

\section{Cytokine (IL-2, IFN- $\gamma)$ assay by ELISA}

Culture supernates were assayed for cytokines in a sandwich ELISA test, by a modification of a published method [13]. Ninety-six well plates were coated by inoculating each well with purified rat monoclonal anticytokine antibody against mouse IL- 2 or IFN- $\gamma$ and 
incubated overnight at $4^{\circ} \mathrm{C}$; these monoclonal antibodies were used at a concentration of $2 \mu \mathrm{g} / \mathrm{well}$ in a volume of $50 \mu \mathrm{l}$. Sites that bind protein non-specifically were blocked by adding PBS containing FCS $10 \%, 200 \mu \mathrm{l} /$ well, for $2 \mathrm{~h}$ at room temperature. The plates were then washed three times with PBS-Tween $200.05 \%$; after this, $100 \mu \mathrm{l}$ of supernate samples or control or medium, were added to each well and the plates were incubated for $2 \mathrm{~h}$ at $37^{\circ} \mathrm{C}$. The plates were again washed with PBS-Tween $0.5 \%$, and $100 \mu \mathrm{l}$ of biotinylated anti-cytokine antibody, $0.5 \mu \mathrm{g} / \mathrm{ml}$, were added to each well. After incubating the plates at $37^{\circ} \mathrm{C}$ for $1 \mathrm{~h}, 100 \mu \mathrm{l}$ of HRP-strep (horseradish peroxidasestreptavidin) at a 1 in 4000 dilution were added to each well, and the plates were incubated at $37^{\circ} \mathrm{C}$ for 30 $45 \mathrm{~min}$. After three further washes with PBS-Tween $0.05 \%, 100 \mu \mathrm{l}$ of substrate $\left(3,3^{\prime}, 5,5^{\prime}\right.$-tetramethyl benzidine $6 \mathrm{mg}$ in $1.0 \mathrm{ml}$ of dimethyl sulphoxide dissolved in $10 \mathrm{ml}$ of acetate buffer and $5 \mu \mathrm{l}$ of $\mathrm{H}_{2} \mathrm{O}_{2}$ ) were added to each well, and the plates were incubated for $30 \mathrm{~min}$ at $37^{\circ} \mathrm{C}$. The reaction was stopped with $50 \mu \mathrm{l}$ of sulphuric acid $10 \%$ and the absorbance value was determined with an Antos Labtec ELISA Reader 2001 at a wavelength of $450 \mathrm{~nm}$. A standard curve was constructed for each plate and for each cytokine from assays of eight double dilutions of recombinant cytokine in triplicate. The sensitivity of the assay was taken as 3 SDs above the mean value from six blank wells; this was $<0.3$ units $/ \mathrm{ml}$ for IL-2 and $<0.11$ units/ $\mathrm{ml}$ for IFN $-\gamma$. The ELISA values of negative controls wDTP, aDTP, PBS were similar to the reading given by blanks.

\section{Statistical analysis}

Comparisons between cytokine production from cultures of splenocytes taken from groups of mice immunised with influenza subunit vaccine in wDTP, $\mathrm{aDTP}$ and saline with respect to the incidence and levels of IL-2 or IFN- $\gamma$ were made by the MannWhitney $\mathrm{U}$ test.

\section{Results}

The $I L-2$ response of spleen cell cultures after immunisation

The IL-2 response of spleen cells from mice given two doses of subunit A/Beijing X109 influenza vaccine in WDTP and re-stimulated in vitro with subunit vaccine was $1.20 \mathrm{SD} 0.09$ on day 7 and $1.10 \mathrm{SD} 0.07$ units $/ \mathrm{ml}$ on day 10 after immunisation, as measured by ELISA (Table 1); the results were essentially the same $(p=>0.05)$. In contrast, the IL-2 responses of restimulated spleen cells taken 7 and 10 days after immunisation with vaccine in aDTP at 7 and 10 days after immunisation were $0.69 \mathrm{SD} 0.01$ and $0.66 \mathrm{SD} 0.01$ units $/ \mathrm{ml}$, respectively (Table 1 ). This result was not significantly different from that produced by cells from animals immunised with subunit vaccine in saline which gave readings of $0.65 \mathrm{SD} 0.04$ and $0.60 \mathrm{SD} 0.04$ units/ $\mathrm{ml}$. When spleen cell cultures were stimulated with live virus, the IL-2 response of cells taken from mice given vaccine in wDTP was $2.20 \mathrm{SD} 0.02$ and $2.00 \mathrm{SD} 0.04 \mathrm{u}-$ nits $/ \mathrm{ml}$ at 7 and 10 days after immunisation; these figures were significantly greater than the response to stimulation with inactivated vaccine $(p=<0.01)$. Small increases were also observed after live virus stimulation of spleen cells from animals immunised with subunit vaccine in aDTP or saline, which were significantly greater than for controls $(p=<0.05)$ and less than for cells from animals immunised with vaccine in wDTP $(\mathrm{p}=<0.01)$. These results, shown graphically in Fig. 1, indicate that the only marked response in IL-2 production was seen in spleen cells from animals given vaccine in wDTP, whilst the response from animals given vaccine in aDTP or saline was similar and relatively small.

Table 1. IL-2 induction in cultures of immune spleen cells re-stimulated in vitro with influenza A/Beijing X109 subunit vaccine or A/Beijing/353/89 virus

\begin{tabular}{lcccc}
\hline & \multicolumn{2}{c}{ LL-2 units (SD)/ml from spleen cells stimulated with } \\
\cline { 2 - 5 } & \multicolumn{2}{c}{ SV } & \multicolumn{2}{c}{ Virus } \\
\cline { 2 - 5 } Vaccine given & 7 days & 10 days & 7 days & 10 days \\
\hline $5.0 \mu \mathrm{g} \mathrm{HA}+$ wDTP & 1.20 & 1.10 & 2.20 & 2.00 \\
& $(0.09)$ & $(0.07)$ & $(0.03)$ & $(0.04)$ \\
$5.0 \mu \mathrm{g}$ HA + aDTP & 0.69 & 0.66 & 0.85 & 0.79 \\
$5.0 \mu \mathrm{g} \mathrm{HA}+$ PBS & $(0.01)$ & $(0.01)$ & $(0.01)$ & $(0.04)$ \\
& 0.65 & 0.60 & 0.78 & 0.70 \\
wDTP & $(0.04)$ & $(0.04)$ & $(0.04)$ & $(0.01)$ \\
& 0.54 & 0.51 & 0.60 & 0.51 \\
aDTP & $(0.01)$ & $(0.01)$ & $(0.01)$ & $(0.01)$ \\
& 0.39 & 0.38 & 0.49 & 0.40 \\
PBS & $(0.01)$ & $(0.01)$ & $(0.01)$ & $(0.01)$ \\
& 0.34 & 0.51 & 0.47 & 0.49 \\
& $(0.07)$ & $(0.01)$ & $(0.02)$ & $(0.05)$ \\
\hline
\end{tabular}

$\mathrm{SV}$, subunit A/Beijing X109 vaccine.

Virus, influenza $A / B e i j i n g / 353 / 89$ virus. 


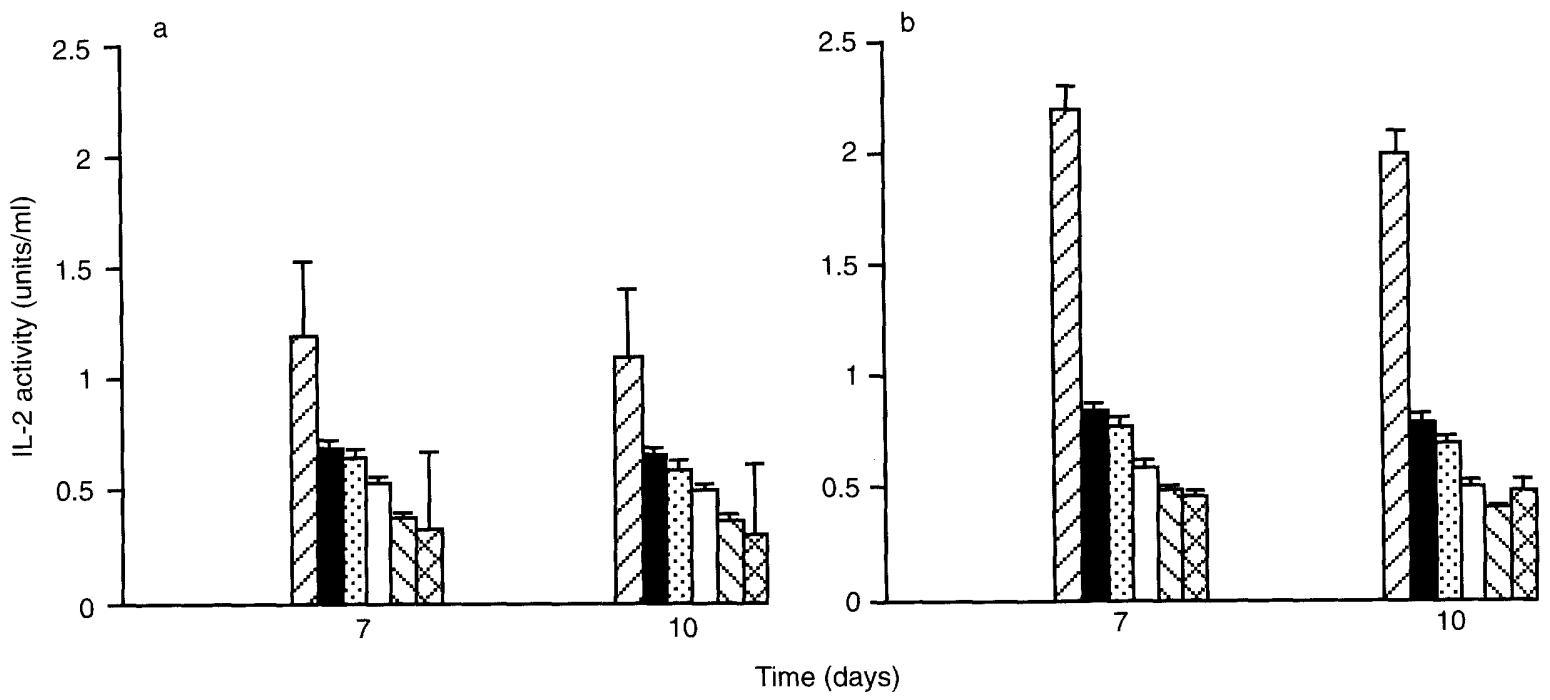

Fig. 1. IL-2 levels in cell supernates after re-stimulation of spleen cells from BALB/c mice immunised twice with $5 \mu \mathrm{g}$ of HA + wDTP ( ); $5 \mu \mathrm{g}$ of HA + aDTP $(\square) ; 5 \mu \mathrm{g}$ of HA + PBS (国); wDTP ( $\square$ ); aDTP (1) and PBS alone ( ). The cells were re-stimulated with (a) subunit influenza A/Beijing X109 vaccine $2 \mu \mathrm{g} / \mathrm{ml}$ or (b) influenza A/Beijing/353/89 virus $(2 \mu \mathrm{g} / \mathrm{ml}$ HA protein $)$.

\section{IFN- $\gamma$ production in spleen cell cultures from immunised animals}

The IFN $-\gamma$ response in spleen cells collected from mice 7 and 10 days after immunisation and re-stimulated with subunit A/Beijing X109 vaccine or influenza A/ Beijing/353/89 virus are shown in Fig. 2. For mice given subunit vaccine in wDTP, the IFN- $\gamma$ response to in-vitro stimulation with subunit vaccine was $0.60 \mathrm{SD} 0.01$ at 7 days and $0.50 \mathrm{SD} 0.03 \mathrm{units} / \mathrm{ml}$ at 10 days after the second immunisation, respectively; this result was significantly greater than controls $(p=<0.01)$. In contrast, the IFN- $\gamma$ response of spleen cells from mice immunised with subunit vaccine in aDTP was $0.40 \mathrm{SD} 0.01$ and $0.35 \mathrm{SD} 0.03$ units $/ \mathrm{ml}$ (Fig. 2), which was significantly greater than controls $(\mathrm{p}=<0.05)$, but significantly less than the IFN- $\gamma$ levels observed in mice given vaccine in wDTP $(\mathrm{p}=<0.01)$. Furthermore, the IFN- $\gamma$ response to spleen cells from animals given subunit vaccine in saline was $0.20 \mathrm{SD} 0.07$ and $0.20 \mathrm{SD} 0.06$ units $/ \mathrm{ml}$ at 7 and 10 days post-inoculation, respectively; this result was significantly lower than the response to vaccine in aDTP $(\mathrm{p}=<0.05)$ and to vaccine in wDTP $(\mathrm{p}=<0.01)$.

The IFN- $\gamma$ response to spleen cells from immunised mice stimulated with live influenza vaccine is shown in Fig. 2. For spleen cells from animals immunised with influenza vaccine in WDTP the response was $1.01 \mathrm{SD} 0.03$ and $0.82 \mathrm{SD} 0.03$ units $/ \mathrm{ml}$; this was significantly greater than the response to cells from other vaccinated groups or controls $(p=<0.01)$. A significant IFN- $\gamma$ response was seen for spleen cells from mice given subunit vaccine in aDTP; the reading were $0.41 \mathrm{SD} 0.03$ and $0.40 \mathrm{SD} 0.02$ units $/ \mathrm{ml}$ at 7 and 10 days, respectively. However, no significant increase was seen for animals given subunit vaccine in saline alone. Thus, the most marked IFN- $\gamma$ responses were seen for animals given vaccine in wDTP; a significant but smaller response was seen for animals given vaccine in aDTP and no significant response was seen in animals given saline alone, compared to controls (Fig. 2).

\section{Discussion}

The currently available inactivated vaccines against influenza confer protection in $60-90 \%$ of vaccinees; the lower rates pertain to the elderly population which is most at risk [1,2]. A more solid immunity has been reported for live influenza virus vaccine [3]. The reasons for these differences are not known; however, the disappointing protection conferred by inactivated vaccine may be due to the relatively poor local antibody production and cell-mediated immune responses which are induced, compared to the responses elicited by live virus infection or attenuated virus vaccines. The cell-mediated immune response to inactivated vaccine is controversial. Some authors have demonstrated induction of an MHC class-I cytotoxic Tcell (CTL) response to inactivated influenza vaccine in both mice and human subjects [14], while others have found this response to be poor and ephemeral [15]. Cell-mediated responses to killed vaccine can be enhanced by immunisation with a suitable adjuvant or carrier; thus, QS-21-, muramyl dipeptide- and ISCOMformulated vaccines are reported to stimulate CTL responses [16-18]. Freund's complete adjuvant is an efficient stimulator of cellular immunity $[19,20]$. None of the above adjuvants is licensed for use in man; the only licensed adjuvants for human use are the aluminium salts which are not efficient mediators of cellular immunity.

Previous studies have shown that inactivated influenza 

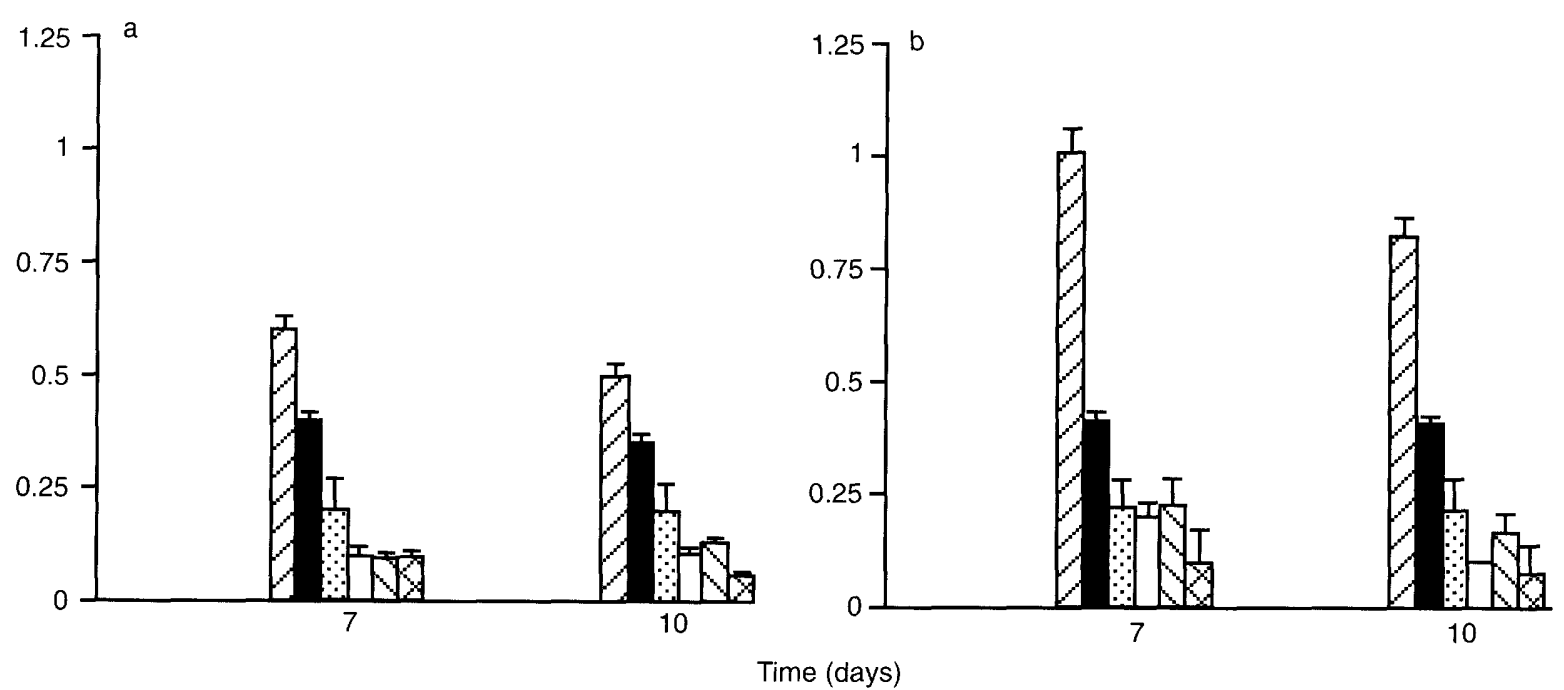

Fig. 2. Concentration of IFN- $\gamma$ in cell supernates after re-stimulation of spleen cells from BALB/c mice immunised

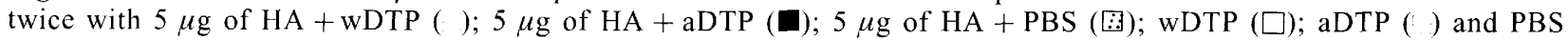
alone ( ). The cells were re-stimulated with (a) subunit influenza A/Beijing X109 vaccine $2 \mu \mathrm{g} / \mathrm{ml}$ or (b) of influenza $\mathrm{A} /$ Beijing/353/89 virus $(2 \mu \mathrm{g} / \mathrm{ml}$ HA protein).

virus vaccine mixed with cellular DTP (wDTP) induced a marked serum antibody response, and broad $\operatorname{IgG}$ subclass antibody responses of $\operatorname{IgG} 2 \mathrm{a}$ and $\operatorname{IgG} 2 \mathrm{~b}$, which suggests induction of a cell-mediated immune response [21]. In addition, vaccine incorporated into wDTP gave a more solid immunity to challenge virus infection, and was $>250$-fold more effective in inducing immunity to challenge virus infection than saline vaccine [10]. An enhanced immune response and immunity to challenge were seen in mice immunised with vaccine plus acellular DTP (aDTP), compared to saline vaccine. However, the humoral antibody response was less, the $\operatorname{IgG} 2 \mathrm{a}$ and $\operatorname{IgG} 2 \mathrm{~b}$ antibody responses were reduced, and protection against challenge infection was found to be significantly less than for vaccine in wDTP [11]. The adjuvant effect was due to the LPS component of DTP [10], and the concentration of this in WDTP was $100-$ fold greater than for aDTP [11]: it was suggested that this difference could explain the better adjuvant effect of wDTP. The adjuvant effect of LPS has been reported by others [22]. The present studies were undertaken to investigate further the cell-mediated immune responses of mice to subunit influenza vaccines administered with wDTP, aDTP or saline. It is known that $\mathrm{CD} 8^{+} \mathrm{CTL}$ induction is dependent on IL-2 and IFN- $\gamma$ from an activated Th- 1 subset of Tlymphocytes; thus, the induction of these two cytokine responses is a measure of a CTL response [21, 23, 24]. These cytokine responses were measured in supernates of T-lyphocyte cultures from immunised mice stimulated in vitro with influenza vaccine or live influenza virus. These results indicate that spleen cells from mice given vaccine in wDTP produced a significant IL-2 and IFN- $\gamma$ response following stimulation by subunit vaccine or live virus. The effect was markedly less for spleen cells from mice immunised with vaccine incorporated into aDTP or saline where the response was small and similar; thus, the findings indicate that immunisation with vaccine in WDTP can induce an $\mathrm{MHC}$ class-I $\mathrm{CD}^{+} \mathrm{CTL}$ response. This confirms the conclusion of this response based on the observation of an IgG2a and IgG2b serum antibody response.

It is suggested that the above cell-mediated immune responses may be responsible for the enhanced immunity to challenge virus infection induced by vaccine in wDTP, which is 100 -fold more effective than that seen in mice given vaccine in aDTP of saline where the cell-mediated immune response was significantly less or undetectable. The enhanced cellmediated immune responses to vaccine in wDTP did not require adjuvant complexed to vaccine, as the effects are observed by simple mixing [10]. Moreover, the results suggest that as wDTP is licensed, it or its components could provide an adjuvant that would enhance the CTL responses against other microorganisms where this response is important in determining immunity, and suggest a strategy whereby influenza vaccines could be given to young children or the elderly, in whom immune responses to saline vaccine are relatively poor and morbidity and mortality are higher than in other age groups.

C.W.P. is supported by the Yorkshire Cancer Research Campaign. The authors are grateful for the generous gift of influenza A/Beijing X109 virus and subunit vaccine and DTP vaccine from Drs 1. Furminger and T. Colgate, Evans Medical, Speke, Liverpool, England. H.T. thanks the Government of Islamic Republic of Iran and the Department of Medical Microbiology, Medical School, University of Esfahan for their support.

\section{References}

1. Potter CW. Influenza. In: Zuckerman AJ, Banatvala JE, Pattison JR (eds) Principles and practice of clinical virology. 
Chichester, John Wiley and Sons. 1994: 230-255.

2. Howells CHL, Vesselinova-Jenkins CK, Evans AD, James J. Influenza vaccination and mortality from bronchopneumonia in the elderly. Lancet $1975 ; 1$ : $381-383$.

3. Potter CW. Attenuated influenza virus vaccines. Rev Med Virology 1994; 4: 279-292.

4. Murphy BR, Clements ML. The systemic and mucosal immune response of humans to influenza A virus. Curr Top Microbiol Immunol 1989; 146: 107-116.

5. McMichael AJ, Gotch FM, Noble GR, Beare PAS. Cytotoxic T-cell immunity to influenza. $N$ Engl $J$ Med 1983; 309: 13-17.

6. Wells MA, Albrecht P, Ennis FA. Recovery from a viral respiratory tract infection. I. Influenza pneumonia in normal and T-deficient mice. $J$ Immunol 1981; 126: 1036-1041.

7. Ada GL, Leung K-N, Erth H. An analysis of the effector T cell generation and function in mice exposed to influenza $A$ or Sendai virus. Immunol Rev 1981; 58: 5-24.

8. McMichael AJ, Gotch FM, Cullen P, Askonas BA, Webster RG. The human cytotoxic $T$ cell response to influenza $A$ vaccination. Clin Exp Immunol 1981; 43: 276-284.

9. Ennis FA, Meager A. Immune interferon produced to high levels by antigenic stimulation of human lymphocytes with influenza virus. J Exp Med 1981; 154: 1279-1289.

10. Potter $\mathrm{CW}$, Tamizifar $\mathrm{H}$, Jennings $\mathrm{R}$. Immune response of mice to immunization with subunit influenza $A$ vaccine in DTP vaccine. Vaccine 1995; 13: 253-260.

11. Tamizifar $\mathrm{H}$, Robinson $\mathrm{A}$, Jennings $\mathrm{R}$, Potter $\mathrm{CW}$. Immune response and protection against influenza $\mathrm{A}$ infection in mice immunised with subunit influenza A vaccine in combination with whole cell or acellular DTP vaccine. Vaccine 1995; 13: $1539-1546$

12. Mosmann TR, Coffman RL. Th1 and Th2 cells: different patterns of lymphokine secretion lead to different functional properties. Annu Rev Immunol 1989; 7: 145-73.

13. Mosmann TR, Fong TA. Specific assays for cytokine production by T cells. J Immunol Methods 1989; 116: 151-158.

14. Ennis FA, Martin WJ, Verbonitz MW. Cytotoxic T lymphocytes induced in mice by inactivated influenza virus vaccine. Nature
1977; 269: 418-419.

15. Webster RG, Askonas BA. Cross-protection and cross-reactive cytotoxic $\mathrm{T}$ cells induced by influenza virus vaccine in mice. Eur J Immunol 1980; 10: 396-401.

16. Rouse BT, Norley S, Martin S. Antiviral cytotoxic T-lymphocyte induction and vaccination. Rev Infect Dis 1988; 10: 16-33.

17. Ben Ahmeida ETS, Gregoriadis G, Potter CW, Jennings R. Immunopotentiation of local and systemic humoral immune responses by ISCOMs, liposomes and FCA; role in protection against influenza A in mice. Vaccine 1993; 11: $1302-1309$

18. Nerome K, Yoshioka Y, Ishida M et al. Development of a new type of influenza subunit vaccine made by muramyl dipeptide liposome: enhancement of humoral and cellular immune responses. Vaccine 1990; 8: 503-509.

19. Allison AC, Gregoriadis G. Liposomes as immunological adjuvants. Nature 1974; 252: 252.

20. Bomford R. Immunomodulation by adjuvants. In: Dimmock NJ, Griffiths PD, Madeley CR (eds) Control of virus diseases. Society for General Microbiology Symposium Series no. 45. Cambridge, Cambridge University Press. 1990: 143-154.

21. Mosmann TR, Cherwinski H. Bond MW, Giedlin A, Coffman RL. Two types of murine helper $T$ cell clone. 1. Definition according to profiles of lymphokine activities and secreted proteins. J Immunol 1986; 136: 2348-2357.

22. Johnson AG, Gaines S, Landy M. Studies on the O antigen of Salmonella typhosa. V. Enhancement of antibody response to protein antigens by the purified lipopolysacharide. $J$ Exp Med 1956; 103: $225-246$.

23. McElhaney JE, Meneilly GS, Pinkoski MJ, Lechelt KE, Bleackley RC. Vaccine-related determinants of the interleukin-2 response to influenza vaccination in healthy young and elderly adults. Vaccine 1995; 13: 6-10.

24. Villacres-Eriksson $M$, Bergstron-Mollaoglu $M$, Kaberg $H$, Morein B. Involvement of interleukin-2 and interferon-gamma in the immune response induced by influenza virus ISCOMs. Scand J Immunol 1992; 36: 421-426. 